\title{
Teesside coronary survey-fatality and comparative severity of patients treated at home, in the hospital ward, and in the coronary care unit after myocardial infarction
}

\author{
A. W. DELLIPIANI, W. A. COLLING, ${ }^{2}$ R. J. DONALDSON, ${ }^{3}$ \\ AND P. MCCORMACK ${ }^{4}$
}

An epidemiological survey of myocardial infarction in Teesside County Borough was completed between April 1972 and April 1973. Cases were notified and divided into those who had suffered a 'definite', 'possible', or 'not' myocardial infarction. Severity factors were measured in the 'definite' cases and the distribution of the various factors studied among home, ward, and coronary care unit treated cases. Increasing severity was found to be related to increased fatality. The fatality of patients treated at home was less than that of those treated in the ward or the coronary care unit. Those who survived to be treated at home were not less severe than those who survived in a comparable group to be treated in hospital using the objective criteria described in the assessment of severity. It is emphasised that the results must be interpreted with caution as other essentially subjective criteria not so easily measurable, but which might have been of considerable influence in the assessment of severity, were not measured in this study.

The Teesside Coronary Survey appeared to show that patients who had suffered a myocardial infarction and were treated at home fared better than those admitted to hospital (Colling et al., 1976). A simple explanation for this might have been that there was a difference in severity between the groups of cases treated. It was essential, therefore, to try to measure severity in these patients. The size of the survey and the fact that many cases were treated at home presented difficulties and precluded using an index such as the Norris Index (Norris et al., 1969) which includes certain physical signs and measurements such as radiological oedema. The Peel Index (Peel et al., 1962) has been widely used in epidemiological work and appeared appropriate to this study.

\section{Methods}

This study is part of an epidemiological survey of coronary artery disease in Teesside County Borough (now part of Cleveland County), carried out in the year April 1972 to April 1973. Details of the organ-

${ }^{1}$ North Tees General Hospital, Stockton-on-Tees.

'General practitioner, Stockton-on-Tees.

${ }^{3}$ London School of Hygiene and Tropical Medicine; formerly Medical Officer of Health, Teesside County Borough.

'Hemlington Hospital.

Received for publication 21 February 1977 isation of the project have been discussed elsewhere (Colling et al., 1976). The object was to study all episodes of myocardial infarction occurring within the Teesside County Borough whether these occurred at home or in hospital. The County Borough had a population of 396230 and was, at the time of the survey, served by 150 general practitioners, 14 hospitals, and 2 coronary care units. The necessary information was obtained by direct contact with patients whenever possible, supplemented by information from their family doctors and the family itself. This information was obtained by 4 specially trained nurses who visited the patients at home, in the hospital ward, or in the coronary care unit, within 24 hours, at 72 hours, and at 28 days after the attack. In addition to completing a detailed form recording symptoms, certain signs, medical, and personal details, an electrocardiogram was recorded and blood samples were obtained for enzyme analysis at the time of the first two visits. Some of these measurements had been obtained by hospital staff in those patients admitted to hospital. Cases were classified using modified WHO criteria (World Health Organization, 1959) as having suffered a 'definite', 'possible', or 'not' myocardial infarction.

The severity index devised by Peel et al. (1962) was modified to incorporate the information that 
Table 1 Modified peel index

\begin{tabular}{|c|c|c|}
\hline & & $\begin{array}{l}\text { Severity } \\
\text { Score }\end{array}$ \\
\hline \multicolumn{3}{|l|}{ Age and sex } \\
\hline$<55$ years & & $\mathbf{0}$ \\
\hline $55-59$ years & & 1 \\
\hline $60-64$ years & $<65$ years & 2 \\
\hline$>65$ years & $>65$ years & 3 \\
\hline \multicolumn{3}{|c|}{ Past history } \\
\hline \multirow{2}{*}{\multicolumn{2}{|c|}{$\begin{array}{l}\text { Previous myocardial infarct } \\
\text { Other cardiovascular disease, exertional dyspnoea }\end{array}$}} & 6 \\
\hline & & 3 \\
\hline \multicolumn{2}{|c|}{ Angina only } & 1 \\
\hline \multicolumn{2}{|c|}{ No cardiovascular disease } & 0 \\
\hline \multicolumn{2}{|c|}{$\mathrm{BP}>100 \mathrm{~mm} \mathrm{Hg}$} & 0 \\
\hline \multicolumn{2}{|c|}{$\mathrm{BP}<100 \mathrm{mmHg}$} & 4 \\
\hline \multicolumn{2}{|c|}{ BP $<100 \mathrm{mmHg}$ with cold extremities } & 7 \\
\hline \multicolumn{3}{|c|}{ Failure } \\
\hline \multicolumn{2}{|c|}{ Not breathless } & 0 \\
\hline \multirow{2}{*}{\multicolumn{2}{|c|}{$\begin{array}{l}\text { Breathless } \\
\text { Electrocardiogram }\end{array}$}} & 4 \\
\hline & & \\
\hline \multicolumn{2}{|c|}{ Normal } & 0 \\
\hline \multicolumn{2}{|c|}{ Normal QRS (i.e. ST and $T$ wave changes) } & 1 \\
\hline \multicolumn{2}{|c|}{ QR } & 3 \\
\hline \multicolumn{2}{|l|}{ QS or BBB } & 4 \\
\hline \multicolumn{2}{|c|}{ Sinus } & 0 \\
\hline \multicolumn{3}{|c|}{ One or more of: } \\
\hline \multicolumn{3}{|c|}{$\begin{array}{l}\text { Atrial fibrillation or flutter; paroxysmal atrial } \\
\text { tachycardia; sinus tachycardia }>110 \text { min; frequent } \\
\text { ectopics; nodal rhythm; or block }\end{array}$} \\
\hline \multicolumn{3}{|c|}{ Aspartate aminotransferase } \\
\hline \multicolumn{2}{|c|}{$<12$ units (normal) } & 0 \\
\hline \multirow{2}{*}{\multicolumn{2}{|c|}{$\begin{array}{l}12 \text { to } 60 \text { units } \\
>60 \text { units }\end{array}$}} & 1 \\
\hline & & 4 \\
\hline
\end{tabular}

nurses had obtained and to include biochemical data (Table 1). The severity scores given to each of the factors in the modified index were derived from the original Peel Index which does not, however, include serum enzyme levels. Appropriate severity scores for the serum aspartate aminotransferase (SGOT) were derived from published reports relating fatality to aspartate aminotransferase levels (Chapman, 1971). The electrocardiographic criteria for infarction and analysis of rhythm changes were taken from the first electrocardiogram, and the aspartate aminotransferase level from the initial estimation either in hospital or at home. The scores obtained were related to fatality defined as death at or within 28 days of the incident.
The study of fatality in relation to severity was confined to patients who had been classified as having had a 'definite' myocardial infarction (a diagnostically well defined group) and had survived long enough to receive care and have the diagnostic investigations applied. Only one patient who was kept at home died between the time of notification and arrival of the nurse.

\section{Results}

The number of cases and corresponding fatality in each group is shown in Table 2. This paper examines the severity, distribution, and fatality of patients with a 'definite' myocardial infarction in group A. In 737 of these the place of treatment was known and their distribution and fatality rates are illustrated in Table 3. When the modified Peel Index was applied to these cases and the banded scores plotted against fatality rates the results are seen in Fig. 1. The regression line is significant $(P<0.01)$, indicating that severity as measured by the Peel Index is related to fatality. The distribution of the modified Peel scores by the three places of treatment is illustrated in Fig. 2. The difference in the percentage of patients in each score group treated at home, in the ward, and in the coronary care unit did not reach statistical significance.

The modified Peel Index did not, therefore, reveal any difference in severity between the patients in the three places of treatment but it is a relatively insensitive index, and in addition missing observations enabled it to be applied to only 590 cases. It was thought possible that the overall index might also mask the effect on fatality of an individual factor in the index. Each factor was, therefore,

Table 3 Crude fatality for 'definite' myocardial infarct only

\begin{tabular}{lccc}
\hline & Home & Ward & $\begin{array}{c}\text { Coronary } \\
\text { care unit }\end{array}$ \\
\hline Total cases & 193 & 296 & 248 \\
Fatality $(\%)$ & 8.8 & 20.7 & 12.8 \\
\hline
\end{tabular}

Table 2 Classification of myocardial infarction

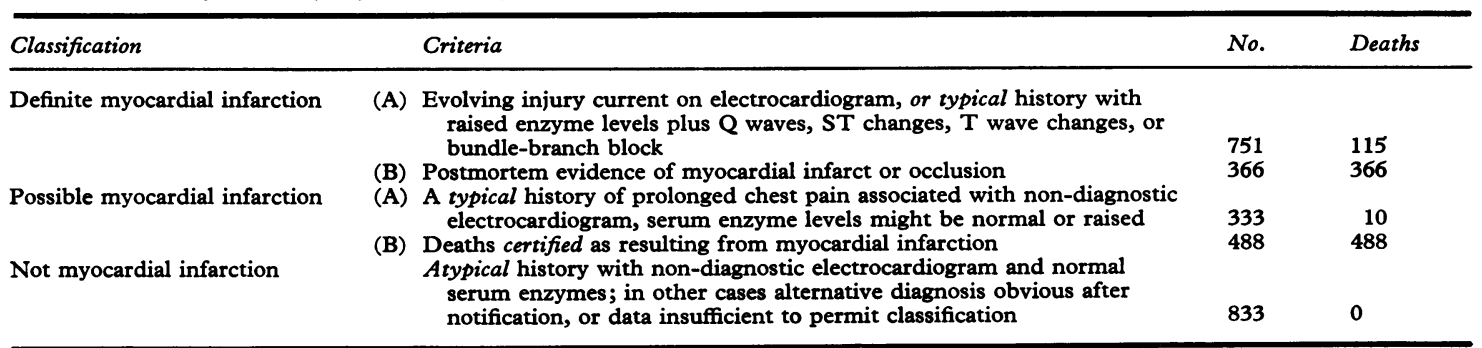


examined independently in relation to fatality. The subsequent tables indicate that the number of missing observations for the individual factors were very few indeed-in all cases less than 5 per cent.

AGE AND SEX

As can be seen from Fig. 3, fatality tends to increase with age and there was no significant difference between the fatality rates for the two sexes. There was a significantly lower fatality, however, in patients who were under 65 years of age than in those who were 65 years of age and over $(P<0.001)$.

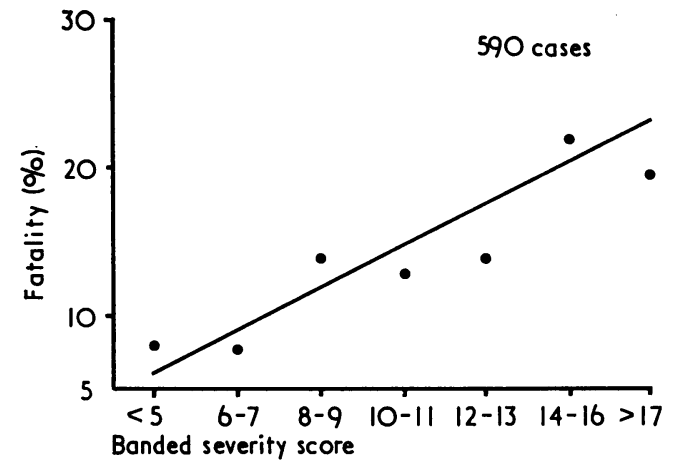

Fig. 1 Severity score related to fatality.

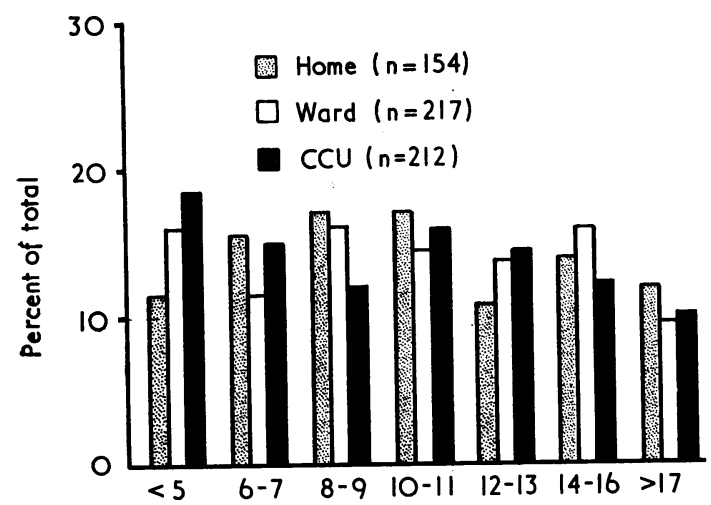

Fig. 2 Severity score related to place of treatment: home, ward, and $C C U$ in each severity band.
Perhaps because of admission policy or some other selective factor, the group with the high fatality rates, i.e. those over the age of 65 , did not go into the Coronary Care Units (Fig. 4). There were 43 per cent of patients over 65 years of age and 81 per cent of these went into the hospital ward or stayed at home. As far as age is concerned, therefore, the coronary care units appear to be treating the milder cases. The crude fatality rates were, therefore,

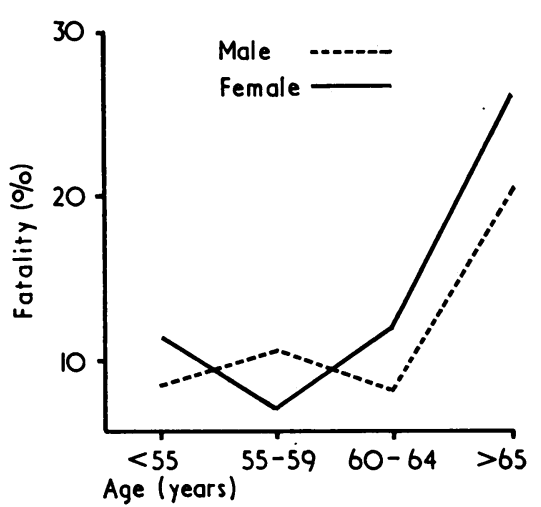

Fig. 3 Fatality related to age and sex.

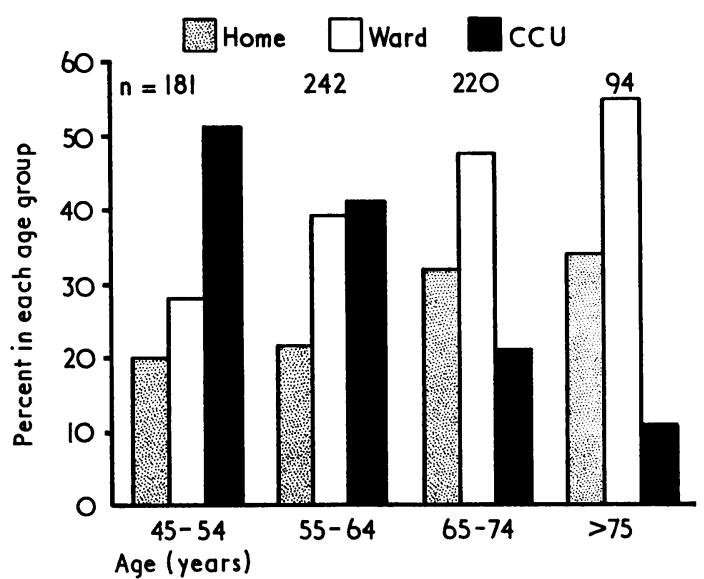

Fig. 4 Age related to place of treatment: home, ward, and $C C U$.

Table 4 Age distribution and fatality by home, ward, and CCU : men

\begin{tabular}{|c|c|c|c|c|c|c|c|c|c|}
\hline Age (y) & $\begin{array}{l}\text { Home } \\
\text { No. }\end{array}$ & Deaths & $\%$ & $\begin{array}{l}\text { Ward } \\
\text { No. }\end{array}$ & Deaths & $\%$ & $\begin{array}{l}C C U \\
\text { No. }\end{array}$ & Deaths & $\%$ \\
\hline $\begin{array}{r}45-54 \\
55-65 \\
65-74 \\
>75\end{array}$ & $\begin{array}{l}31 \\
33 \\
45 \\
12\end{array}$ & $\begin{array}{l}2 \\
1 \\
4 \\
3\end{array}$ & $\begin{array}{r}6.5 \\
3.0 \\
8.9 \\
25.0\end{array}$ & $\begin{array}{l}41 \\
61 \\
62 \\
20\end{array}$ & $\begin{array}{r}4 \\
5 \\
12 \\
8\end{array}$ & $\begin{array}{r}9 \cdot 8 \\
8 \cdot 2 \\
19 \cdot 4 \\
40 \cdot 0\end{array}$ & $\begin{array}{r}75 \\
74 \\
25 \\
4\end{array}$ & $\begin{array}{l}6 \\
8 \\
6 \\
1\end{array}$ & $\begin{array}{r}8 \cdot 0 \\
10 \cdot 8 \\
24 \cdot 0 \\
25 \cdot 0\end{array}$ \\
\hline Standardised fatality $\%$ & & & $7 \cdot 3$ & & & $14 \cdot 1$ & & & $14 \cdot 6$ \\
\hline
\end{tabular}


Table 5 Age distribution and fatality by home, ward, and CCU : women

\begin{tabular}{|c|c|c|c|c|c|c|c|c|c|}
\hline Age (y) & $\begin{array}{l}\text { Home } \\
\text { No. }\end{array}$ & Deaths & $\%$ & $\begin{array}{l}\text { Ward } \\
\text { No. }\end{array}$ & Deaths & $\%$ & $\begin{array}{l}\text { CCU } \\
\text { No. }\end{array}$ & Deaths & $\%$ \\
\hline $\begin{array}{c}45-54 \\
55-64 \\
65-74 \\
>75\end{array}$ & $\begin{array}{r}6 \\
20 \\
26 \\
20\end{array}$ & $\begin{array}{l}0 \\
2 \\
2 \\
3\end{array}$ & $\begin{array}{c}0 \\
10 \cdot 0 \\
7 \cdot 7 \\
15 \cdot 0\end{array}$ & $\begin{array}{l}11 \\
30 \\
40 \\
31\end{array}$ & $\begin{array}{r}1 \\
5 \\
13 \\
13\end{array}$ & $\begin{array}{r}9 \cdot 1 \\
16 \cdot 7 \\
32 \cdot 5 \\
42 \cdot 0\end{array}$ & $\begin{array}{r}17 \\
24 \\
22 \\
7\end{array}$ & $\begin{array}{l}3 \\
2 \\
4 \\
2\end{array}$ & $\begin{array}{r}17 \cdot 6 \\
8 \cdot 3 \\
18 \cdot 2 \\
28 \cdot 6\end{array}$ \\
\hline "Standardised fatality \% & & & $9 \cdot 0$ & & & 26.9 & & & $17 \cdot 6$ \\
\hline
\end{tabular}

Table 6 Fatality relating to past history

\begin{tabular}{lrl}
\hline Past history & No. & Fatality $\%$ \\
\hline Nil & 372 & $15 \cdot 6$ \\
Angina & 78 & $17 \cdot 9$ \\
Other cardiovascular disease & 80 & $15 \cdot 0$ \\
Myocardial infarction & 190 & $15 \cdot 8$ \\
\hline & 720 & \\
\hline
\end{tabular}

weighted appropriately so as to standardise the effect of age on fatality rates. The results for each sex are illustrated in Tables 4 and 5.

\section{PAST HISTORY}

When the fatality rates of cases with a past history of angina, other cardiovascular disease, or myocardial infarction were compared with those without such a past history, no statistical significance was found (Table 6). Furthermore, the distribution of past history by home, ward, and coronary care unit was found to be similar.

\section{SHOCK}

Peel and his colleagues did not define shock clearly and in this survey a definition of shock (warm or cold) was a systolic blood pressure of less than $100 \mathrm{mmHg}$. Of the 721 'definite' cases in which the measurements were obtained ( $96 \%$ of total cases), 8.7 per cent had such a blood pressure compared with 12 per cent in the Bristol series (Mather et al., 1971). However, the fatality rates for those with a blood pressure level of more than $100 \mathrm{mmHg}$ was 14.3 per cent and this did not differ significantly from those with a blood pressure of $100 \mathrm{mmHg}$ or less $(17.5 \%)$. The few cases with a low blood pressure (63) appeared to be equally distributed between the home, ward, and coronary care unit.

Table 7 Fatality related to breathlessness

\begin{tabular}{lll}
\hline & No. & Fatality \% \\
\hline Not breathless & 541 & $13 \cdot 3$ \\
Breathless & 174 & $20 \cdot 1$ \\
\hline & 715 & \\
\hline
\end{tabular}

CARDIAC FAILURE

This was assessed by the presence or absence of breathlessness and was associated with a significantly increased fatality rate $(P<0.01)$ (Table 7). Breathlessness was, however, related very significantly to increasing age $(P<0.001)$ which was considered to be the more important variable in this context.

\section{EXTENT OF INFARCTION ON}

ELECTROCARDIOGRAM

Fatality increased significantly with increasing electrocardiographic severity $(P<0.01)$ (Table 8 ). The extent of the infarction on the electrocardiogram was unrelated to age and was evenly distributed between home, ward, and coronary care unit.

\section{ARRHYTHMIAS}

The presence of arrhythmias as listed in Table 1 and as assessed from the first electrocardiogram doubled fatality $(21.5 \%$ as compared to $10.4 \%)$ $(\mathbf{P}<0.01)$. Approximately 30 per cent of patients had some form of arrhythmias on the first electrocardiogram. Of home cases 26 per cent, of ward cases 32.5 per cent, and of coronary care unit cases 32.5 per cent had abnormal rhythms, differences that

Table 8 Fatality related to extent of infarction

\begin{tabular}{lcc}
\hline Electrocardiographic changes & No. & Fatality $\%$ \\
\hline Normal & 157 & $8 \cdot 9$ \\
Intramural & 196 & $11 \cdot 2$ \\
QR & 157 & $21 \cdot 0$ \\
QS: BBB & 241 & $19 \cdot 1$ \\
\hline & 751 & \\
\hline
\end{tabular}

Table 9 Fatality related to aspartate aminotransferase level

\begin{tabular}{|c|c|c|}
\hline Aspartate aminotransferase $I U / l$ & No. & Fatality \% \\
\hline $\begin{array}{r}<12 \\
12-60 \\
>60\end{array}$ & $\begin{array}{l}143 \\
399 \\
170\end{array}$ & $\begin{array}{r}9 \cdot 1 \\
12 \cdot 7 \\
23 \cdot 7\end{array}$ \\
\hline$>60$ & 712 & \\
\hline
\end{tabular}




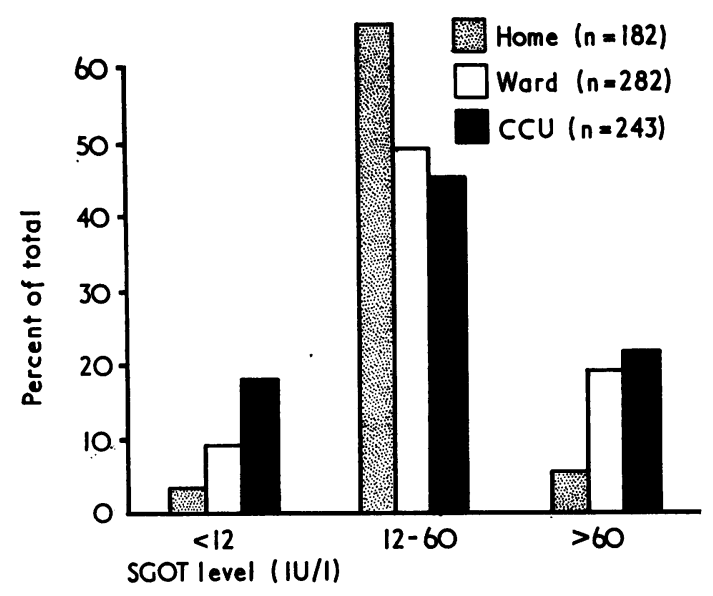

Fig. 5 Aspartate aminotransferase level related to place of treatment: home, ward, and CCU.

were not statistically significant. The incidence of arrhythmias was independent of age.

ASPARTATE AMINOTRANSFERASE LEVEL

The normal level in this study was $<12$ IU units per litre. Fatality increased overall with higher aspartate aminotransferase levels (Table 9). The differences were significant only between groups of patients who had levels of less than 60 and those with levels of greater than 60 units per litre $(P<0.001)$. The influence of the aspartate aminotransferase on fatality was found to be independent of age, sex, and the extent of infarction as measured on the electrocardiogram. The distribution of the aspartate aminotransferase levels between the home, the ward, and the coronary care unit was not even (Fig. 5). Thus 80 per cent of cases with levels of greater than 60 units per litre, i.e. those cases with the higher fatality rates, tended to go into the ward or into the coronary care unit. There were 170 such cases $(23.9 \%$ of the total). Because of the unequal distribution, the crude fatality rates were standardised for this aspartate aminotransferase factor and such standardisation did not materially alter the crude fatality rates (Tables 10,3 ).

\section{Discussion}

Two methods have been used to assess the severity of cases who had suffered a 'definite' myocardial infarction and survived sufficiently long to come under medical care. The first involved the use of an index of severity based on that of Peel and his colleagues. The severity scores for the cases in the three places of treatment were similar. However, the index is a relatively crude indicator of severity. In the second method the individual severity factors were related to fatality, and it is apparent that the weightings given by Peel to certain of the factors are incorrect in the Teesside context. Again from this second part of the analysis it seems that for most of the factors increasing severity was associated with increasing fatality. The two exceptions are a previous history of myocardial infarction, contrary to the experience of Peel and his colleagues (1962), and the presence of shock, which is contrary to the experience of other observers, including Mather et al. (1971). A possible explanation for this latter finding is that blood pressures taken at the time of hospital admission were not necessarily comparable with those taken by the nurses when they visited the patient at home.

The only two factors in the index with a significant effect on fatality, which were unequally distributed between the home, the ward, and the coronary care unit, were age (over 65 years) and aspartate aminotransferase (greater than 60 units per litre). The latter variable was present in a relatively small number of patients and it is, therefore, not surprising that it was only standardisation for age that made an appreciable difference to the crude fatality rates obtained (Tables 4,5 ).

Clearly then cases with a 'definite' myocardial infarction who survived to be treated did better at home than in hospital regardless of whether hospital treatment was in the ward or in the coronary care unit. Women treated in the ward appeared to do particularly badly. It is of interest to see the effects of three of the risk factors studied, age, aspartate aminotransferase level, and extent of infarction on the electrocardiogram, on fatality rates in the three

Table 10 Aspartate aminotransferase distribution and fatality by home, ward, and CCU

\begin{tabular}{|c|c|c|c|c|c|c|c|c|c|}
\hline Aspartate aminotransferase (units) & $\begin{array}{l}\text { Home } \\
\text { No. }\end{array}$ & Deaths & $\%$ & $\begin{array}{l}\text { Ward } \\
\text { No. }\end{array}$ & Deaths & $\%$ & $\begin{array}{l}C C U \\
\text { No. }\end{array}$ & Deaths & $\%$ \\
\hline $\begin{array}{r}<12 \\
12-60 \\
>60\end{array}$ & $\begin{array}{r}36 \\
120 \\
26\end{array}$ & $\begin{array}{l}3 \\
9 \\
2\end{array}$ & $\begin{array}{l}8 \cdot 3 \\
7 \cdot 5 \\
7 \cdot 7\end{array}$ & $\begin{array}{r}48 \\
162 \\
74\end{array}$ & $\begin{array}{r}5 \\
30 \\
23\end{array}$ & $\begin{array}{l}10.5 \\
18.5 \\
31.0\end{array}$ & $\begin{array}{r}59 \\
117 \\
70\end{array}$ & $\begin{array}{r}5 \\
13 \\
15\end{array}$ & $\begin{array}{r}8.5 \\
11 \cdot 1 \\
21 \cdot 4\end{array}$ \\
\hline Standardised fatility & & & $7 \cdot 7$ & & & $19 \cdot 9$ & & & $13 \cdot 1$ \\
\hline
\end{tabular}




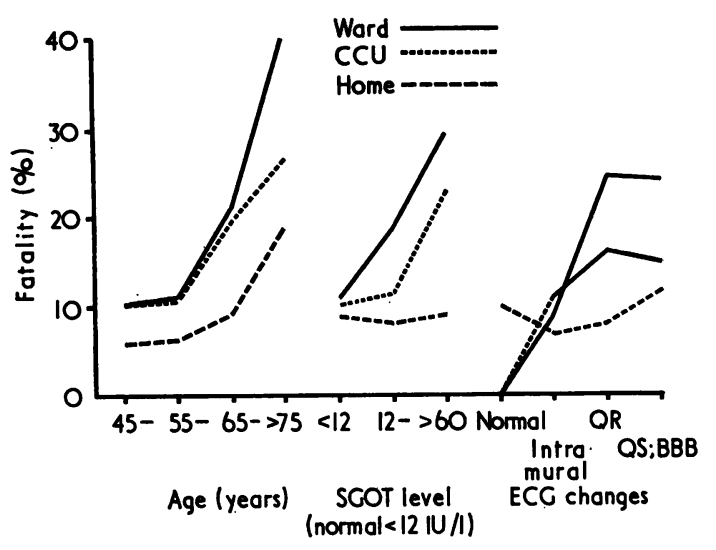

Fig. 6 Fatality related to age, aspartate aminotransferase, and electrocardiogram at places of treatment.

places of treatment (Fig. 6). For all degrees of severity patients did better at home.

Important in the interpretation of the data is the fact that low fatality rates at home might possibly indicate that some home treated cases had not been notified to the survey. It has been emphasised elsewhere (Colling et al., 1976) that many precautions were taken to ensure complete notification. This included exhaustive consultation with hospitals and general practitioners, the registrar of births, deaths and marriages, the coroner, the Teesside Medical Relief Service, the Bed Bureau, and industrial medical officers. In addition weekly lists of deaths relating to the Teesside population sent automatically to the Health Department were studied and details of relevant cases were extracted by the team's staff. None the less it was important to be sure that general practitioners had notified home deaths. A retrospective analysis was initiated to try and elucidate this matter further. All cases certified as having died from myocardial infarction either on clinical or postmortem evidence, who were visited by the general practitioner within 4 days before death during the first 6 months of the survey were analysed. From this study it was calculated that over the year approximately 10 to 12 home treated deaths may not have been notified. These numbers would alter the fatality rates but not to the point of removing the advantage for the home treated cases, especially after standardising for the effect of age on fatality rates.

A discussion on this subject should comment on the delay experienced by the different groups of cases before they came under medical care. Different delays will influence observed fatality rates because of the high fatality known to complicate myocardial infarction in the first two hours after onset. This was confirmed by the Teesside survey (Colling et al., 1976).

In the Teesside survey an important difference between the home and the hospital group was that for home cases the median interval between the onset of the attack and the arrival of the general practitioner was approximately twice as long as for those admitted to hospital (2.63 hours as compared to 1.3 hours). However, the delay in moving patients to hospital increased the median time of patients coming under care in hospital to just under 3 hours, i.e. similar to the delay at home. During this time some patients died while being transferred to hospital but these are excluded from the hospital deaths. Comparison of the fatality rates between the home and the hospital group of cases is, therefore, valid providing the cases can be shown to be of similar severity.

Though the two groups are, therefore, comparable it is not possible to be certain that the first clinical assessment was made at a similar time within the 24-hour interval after onset in the home and hospital groups. Certain of the objective criteria which have been applied as measurements of severity-age, sex, and past bistory will not be affected by such differences, but this is not necessarily the case with the other variables (see Table 1). It will be recalled, however, that these measurements were repeated at 72 hours. When they were analysed in the manner already discussed for the first measurements, i.e. in terms of fatality and between the three treatment venues, the results were similar to those obtained using the first measurements.

It could be argued that the shorter time interval of general practitioner attendance for hospital cases than home cases relates in some way to severity. The main cause of delay in this, as in other studies, was 'patient delay' (Colling et al., 1976). It is possible that the more severe episodes resulted in a shorter 'patient delay' interval and that the sense of urgency was also transmitted to the general practitioner, who attended earlier and tended to admit these cases. This may be an important severity factor which was not measured because it cannot be measured. Indeed it must be admitted that there may be many other factors making up 'severity' which cannot be measured. How important these might be in relation to the objective criteria which have been described and related to fatality in this study can only remain speculative.

It must be emphasised that apart from any reservations about the validity of interpreting severity factors, this study is not intended to resolve the debate as to whether home or hospital is the best 
place to treat patients with a myocardial infarction. It does indicate that for those who have survived the 3-hour interval from apparent onset, the coronary care unit may have little to offer and this has important implications because it is a reasonable supposition that similar delays exist before admission in many hospitals which otherwise run efficient coronary care units. The study we feel indicates more than ever the need to make coronary care unit facilities available to cases earlier so that their potential impact on fatality can be assessed. We have, in fact, established such facilities on Teesside, and a report of their efficacy will be the subject of a further communication.

\section{Conclusion}

The comparative fatality figures presented here suggest that for those patients admitted to hospital coronary care units were of benefit, especially if the patient was a woman. There appears, however, to be little evidence that coronary care units benefited the patients who had survived at home for the median interval ( 3 hours) before they came under the care of the general practitioner. The data presented suggest that the cases treated at home were of similar severity to those treated in hospital as assessed by the objective criteria which have been described and applied to them, even though the reservations which are associated with this exercise are emphasised.

We are grateful to all the nurses and doctors on Teesside who contributed by collecting information for this survey and to their secretaries who notified the cases. We would especially like to thank Sisters E. Young, C. Kirby, C. Smith, and Staff Nurse C. Wylie who worked more than full-time on the project, and Mr. O. Downing who co-ordinated the routine work so effectively; Mrs. S. Hyde and Mr. M. Byrne who, with Mrs. J. Garlick, analysed the data and prepared a preliminary report. Mr. K.
Coates, Research Officer, other members of the Teesside Health Department, and the Statistical Section of the Northern Regional Health Authority gave invaluable assistance. We are also grateful to Dr. E. W. Walton, the late Dr. S. Ray, and staff for their pathology services; to Mr. F. E. Harper, Biochemist; to Mr. M. Sheffield, coroner; and Mr. E. Gifford, chief ambulance officer and many others who helped in vital ways; and also to Professor J. N. Morris, Professor D. G. Julian, Dr. M. Oliver, and Dr. H. Tunstall Pedoe, who gave valuable help in the planning stages.

The research was supported by a generous grant from the Newcastle Regional Hospital Board and completed with extensive help from the Teesside County Borough Council.

\section{References}

Chapman, B. L. (1971). Correlation of mortality rate and serum enzymes in myocardial infarction. British Heart fournal, 33, 643-646.

Colling, A., Dellipiani, A. W., Donaldson, R. J., and MacCormack, P. (1976). Teesside coronary survey. British Medical fournal, 2, 1169-1172.

Mather, H. G., Pearson, N. G., Read, K. L. Q., Shaw, D. B., Steed, G. R., Thorne, M. G., Jones, S., Guerrier, C. J., Eraut, C. D., McHugh, P. M., Chowdhury, N. R., Jafary, M. H., and Wallace, T. J. (1971). Acute myocardial infarction: home and hospital treatment. British Medical fournal, 3, 334-338.

Norris, R. M., Brandt, P. W. T., Caughey, D. E., Lee, A. J., and Scott, P. J. (1969). A new coronary prognostic index. Lancet, 1, 274-278.

Peel, A. A. F., Semple, T., Wang, I., Lancester, W. M., and Dall, J. L. G. (1962). A coronary prognostic index for grading the severity of infarction. British Heart fournal, 24, 745-760.

World Health Organization (1959). Hypertension and coronary heart disease: classification and criteria for epidemiological studies. World Health Organization. Technical Report Series, No. 168.

Requests for reprints to Dr. A. W. Dellipiani, North Tees General Hospital, Hardwick, Stockton-on-Tees, Cleveland TS19 8PE. 